\title{
Diplomatic Strategy between Indonesia-Australia through Politeness Strategy in Pragmatic Study
}

\author{
Rosaria Mita Amalia*, Elvi Citraresmana, Nurul Hikmayaty Saefullah \\ Department of Linguistics, Faculty of Cultural Sciences, Universitas Padjadjaran, Sumedang, Jawa Barat \\ 45363, Indonesia
}

*Corresponding Author: Rosaria Mita Amalia, Department of Linguistics, Faculty of Cultural Sciences, Universitas Padjadjaran, Sumedang, Jawa Barat 45363, Indonesia

\begin{abstract}
Australian and Indonesia cooperate in some fields namely politics, economics, education, culture, and some more. The matters discussed between Australian and Indonesia are bilateral cooperation, espionage allegations, people smuggling, Schapelle Corby, and Papua provinces. This research aims to identify and analyze types of situation that embody the utterances found in diplomatic press release transcription and politeness strategies used in each situation. This research uses qualitative approach by applying Joos (Joos 1967) and Chaer (1995) theory about types of situation, Austin (1962), Searle (1979), dan Loxely (2007) theory about utterances and speech acts, and politeness strategies theory by Brown dan Levinson (1983). The data is collected through diplomatic press release transcription written in English from Ministry of Foreign Affairs the Republic of Indonesia. The result shows that type of situation that embodies in diplomatic press release transcription is consultative style because it occurs in semi-formal situation. The politeness strategies used in diplomatic press release transcription is Face Threatening Act (FTA) off-record which shows that the speaker tries to do saving-face and his utterances has other meaning beyond it.
\end{abstract}

Keywords: Australia, diplomatic strategies, Indonesia, politeness strategies

\section{INTRODUCTION}

Language has a very crucial role in human life because language is a medium for humans to communicate. Through language, people can convey ideas, thoughts, feelings and desires. As language develops, the analysis of language aspects will grow. Wrong communication can be found in a conversation/dialogue between participants known as speakers and hearers. In an utterance, the speaker must pay close attention to the profound situations towards the speaker's interpretation, such as who is the speaker, where, when, and how the speaker the speaker's situation at that time.

In diplomacy field, sometimes the government delivers some diplomatic remarks/responses through people like Minister of Foreign Affairs. In diplomatic note, speakers use politeness strategies to seek or strengthen threats to the face of the hearer (face threatening act). Speakers can also use a politeness strategy to save his own face. Face in this case, not only personally to the speaker's self, but also shows the image of the country represented by him. This research will provide a description of language role through the concept of politeness.

The diplomats and nation ambassadors will get benefit from this research. They can use the concept of politeness. They can learn English that is used in the field of Linguistics and diplomacy; also, they will know and utilize the benefits by adding knowledge through pragmatic in the field of diplomacy.

The linguistics theories used in this research are Joos (1967) and Chaer (1995) theory about types of situation, Austin (1962), Searle (1979), and Loxely (2007) theory about utterances and speech acts, and politeness strategies theory by Brown and Levinson (1983). Types of situation according to Joos (1967) are frozen, formal, consultative, casual, and intimate.

The issues of espionage allegation, people smuggling, Schapelle Corby and Papua province have become major issues for both countries, which may cause harms to the bilateral relation between two countries. At 2002, both governments agreed to establish political dialogue forum named The Bali Process, which is co-chaired by both governments and supported by the United Nations. However, back in 2011, this particular issue had almost harmed the bilateral relation between both governments. 
From this preliminary theory, it is considered that the politeness strategy performed during diplomatic communication is mostly FTA off-record strategy, while the situation that embodies in diplomatic press release transcription is consultative style. Therefore, the formulations of this study are: what types of situations used in diplomatic press release transcription? And what types of politeness strategy found in the implementation for framework? This research applies qualitative method to answer this question.

\section{LITERATURE REVIEWS}

\subsection{Types of Situations}

Types of language in different situation are divided into five, according to Joos (1967). These types are also called as register. These five registers are frozen, formal, consultative, casual, and intimate. Each register shows the level of formality and its usage depends on the relationship between the two participants in the conversation.

\subsubsection{Frozen}

This type is usually used in very formal setting. It does not require any feedback from the audience. The speaker of frozen style usually uses long sentences with good grammar and vocabulary. This type of communication is generally used in respectful situation. For example, speech for a state ceremony, marriage ceremony, national pledge, and so on.

\subsubsection{Formal}

Formal type is used in speaking to medium or large group, also to older persons or professional. In this situation, speaker must frame the whole sentences first before they are delivered. It is better for speaker to avoid using slang terminologies. This type of situation is generally used in meeting, school lessons, court, and in interview.

\subsubsection{Consultative}

Consultative type is usually applied in semi-formal communication and two-way conversation. This type is mostly operated among others. The speaker does not need to plan what he wants to say because it is spontaneous. The utterances may be shorter. Consultative regularly found in regular conversation at school, companies, group discussion, and so on.

\subsubsection{Casual}

Casual language is normally applied between friends thus the situation is mostly relaxed and informal.The interlocutors focus on getting the information out. They tend to use slang in the utterance. Commonly, the relationship between speaker and hearer is closed. This casual language happens in casual conversation with friends, family members, messages, chats, and phone calls.

\subsubsection{Intimate}

This type is different from others. It usually happens within family or very close friends. It uses personal language codes thus not everyone knows the message of the utterances. The use of grammar is unnecessary here. Intimate type usually contains slang, medical terms, and so on.

\subsection{Context}

Pragmatics, according to Fromkin et al., is the study of how context affects meaning (2013: 140). Cutting (2008: 2) defined context as knowledge both shared by speaker and hearer. Cutting classified context into:

- Situational context: refers to the physical situation or background where the conversation between speaker and hearer is taking place.

- Background knowledge: there are two types of background knowledge. Cultural general knowledge is common knowledge that most people already acknowledge. Interpersonal knowledge is specific knowledge that is only shared by speaker and hearer and can only be attained through verbal interaction and physical experience between speaker and hearer. 
- Co-textual context: context that is constructed within the text itself, and often marked by grammatical cohesion and lexical cohesion.

\subsection{Politeness Strategy: Off-Record}

Brown and Levinson (1987) stated that off-record strategy is a way to do FTA by letting the hearer to decide how to interpret what the speaker says. In other words, this strategy is the opposite of on record strategy, where the hearer cannot put himself in certain meaning. The examples of off record strategy are metaphor, irony, rhetorical question, understatement, and so on. This type of politeness strategy lead to the ambiguity.

\section{Methods}

The research uses a qualitative research. According to Djadjasudarma (1993:1), descriptive analysis method is a method that can descriptively provide characteristics, properties and image data through data selection, after the data is collected. In this research, there are the three stages to be done, namely: data provision, data analysis, and presentation or formulation of the analysis result. Researchers will use a variety of literature related to the research topic.

\subsection{Data Collection}

In this research, the writers collect all data from press release transcript of Julie Isabel Bishop is an Australian politician, serving as the Minister for Foreign Affairs since 2013. The transcript contains a conversation between Julie Isabel Bishop with a journalist talking about a bilateral relationship between Australia and Indonesia. Some subjects that talking are bilateral cooperation, espionage allegations, people smuggling, the case of Schapelle Corby, and Papua provinces.

\subsection{Data Analysis}

All of data shows that politeness strategy used in diplomatic press release is politeness strategy offrecord. Here are the data analyzed:

Data 1:

I am not going to go into the details of the discussion I had with Minister Natalegawa. The issue was raised. I took on board the concerns that have been raised and I took them very seriously, but I am not going to go into the details of the discussion because Australian governments do not discuss intelligence matters and that's been a long standing practice of successive governments.

Data (1) is the opening question of the journalist toward Julie Bishop. In this data, Julie Bishop avoids giving a comment regarding the case of espionage done by Australia. In this data, Julie Isabel Bishop uses two clauses indicating his response to the question and also showing that she do politeness strategy off-record. The first clause is "I am not going to go to into detail of the discussions." The second clause is "but I am not going to go into the details of the discussion". In addition, she also adds the reason why she does not want to go into detail of the discussions by saying "because Australian governments do not discuss intelligence matters".

The answer leads the journalist (the hearer) interpret what she says because she does not give direct and clear answer about the matters. With respect the answer, Julie Bishop do politeness strategy offrecord in this data.

Data 2:

The Australian Government does not, as a matter of principle does not, comment on intelligence matters.

Data (2) which written in active transitive structure is a response of Julie Isabel Bishop toward a question about intelligence matters especially espionage allegations done by Australia. Here, Julie Isabel Bishop responses by saying "The Australian Government does not, as a matter of principle does not, comment on intelligence matters". Moreover, the word "does not comment on intelligence matters" indicates that she does not want to talk about the matters. In addition, she also says "as a matter of principle does not" emphasizing her response toward the question. 
It can be concluded that Julie Isabel Bishop applies politeness strategy off-record by giving the indirect answer to avoid giving comment on intelligence matters. It leads the journalist (the hearer) to interpret what Julie Bishop (the speaker) means by saying that. According to the data, Julie Bishop is trying to do FTA by letting the journalist (the hearer) interpret what is she says.

Data 3:

I understand that Minister Scott Morrison has given a press conference today with an update on this matter. I am aware of it, but it is an operational matter. It's currently under discussion and it wouldn't be appropriate for me to comment at all while discussions with Indonesia are underway and while operations are underway.

Data (3) which is response of Julie Bishop regarding to an incident involving an asylum seeker vessel shows that Julie Bishop avoids answering the question indirectly. She emphasizes that what the journalist tries to ask is operational matters. Hence, she has no right to give the comment about the case.

Julie Bishop seems to do FTA by giving indirect answer for the journalist (the hearer). In addition, she says that the case has been already discussed in a press conference by Minister Scott Morrison "...Minister Scott Morrison has given a press conference today with an update on this matter." This answer indicates that she answers the question indirectly. Moreover, she says that it is "an operational matter" so it is not appropriate for her to comment "it wouldn't be appropriate for me to comment at all". It can be seen that she also answers the question indirectly.

Therefore, there answers indicate that Julie Bishop in this data applies politeness strategy off-record by giving the indirect answer and letting the journalist (the hearer) interpret what she says.

Data 4:

These are matters that I believe are best handled outside the media. I don't think it's in the interests of any of the people affected to have a running commentary through the media, but these are matters where Australia and Indonesia are working very closely and cooperatively to get positive outcomes.

Data (4) is response for the case of Schapelle Corby's parole. It is very clear that Julie Isabel Bishop gives the ambiguous answer by saying that the matters "are best handled outside the media". It can be that Julie Isabel Bishop does not want response question clearly. In addition, Julie Isabel Bishop also gives what the expectation of Australia and Indonesia in every matter they are working on. However, this answer also shows ambiguity by saying "but these are matters where Australia and Indonesia are working very closely and cooperatively to get positive outcomes." Julie Isabel Bishop says Australia and Indonesia expect to get positive outcomes but she does not say clearly the positive outcomes that she means.

In data (4), Julie Bishop uses two clauses showing ambiguity answers. The first clause is "are best handled outside the media". The second is but these are matters where Australia and Indonesia are working very closely and cooperatively to get positive outcomes". Both clauses show that Julie Bishop does FTA by not answering the question directly. In addition, she avoids answering the question in order to do FTA. Here, Julie Bishop gives ambiguity answer in order to the journalist (the hearer) interprets what she says.

Data 5:

The Australian Government respects Indonesia's territorial sovereignty in all matters and as Prime Minister Abbott said when he visited Jakarta and met with President Yudhoyono, werespect Indonesian territorial sovereignty when it comes to the Papuan territories.

Data (5) shows the response of Julie Isabel Bishop regarding to Australian foreign policy in relation to the Free West Papua movement. Julie Isabel Bishop in his answer uses the word 'respect( $(s)$ ' that contains ambiguity. Moreover, she uses the word 'respect(s)' two times that indicates she emphases what the Australian Government responses to the Free Papua West.

In addition, the interviewer address directly the question to Julie Isabel Bishop as Foreign Minister of Australia "How is your Australian foreign policy in relation to the Free West Papua movement?" by 
using possessive pronoun 'your', the interview wants to get an answer from Julie Isabel Bishop representing herself as the Foreign Minister of Australia but Julie Isabel Bishop answer the question by using 'The Australian Government; moreover she uses pronoun ' $w e$ ' to describe that she does not represent as herself as Foreign Minister of Australia but as The Australian Government. In addition, she answers the question by using Prime Minister Abbott's opinion.

In data (5), Julie Bishop uses the word 'respect(s)' containing ambiguity and also represents the Australian Government by using the words 'the Australian Government' and 'we'; moreover, she quotes indirectly what Prime Minister Abbott said when he met President Yudhoyono in Jakarta. It can be concluded that Julie Isabel Bishop gives ambiguity answer toward the question. Hence, it is categorized as off-record by using ambiguity answer and letting the journalist (the hearer) interpret the meaning of what she says.

\section{RESUlts AND Discussion}

\subsection{Type of Situation}

In the conversation, communication occurs between the journalist and especially Julie Isabel Bishop, who responses some question from the journalist, is in consultative style. It shows that the communication applies in semi-formal communication and two-way conversation. The speaker does not need to plan what she wants to say because it is spontaneous. The utterances may be shorter. In fact, the data is proper categorized as consultative style.

\subsection{Situational Context}

The situational context in the communication is taking place when Indonesia and Australia is holding an annual politic dialogue forum named The Bali Process. The Bali Process is an official international forum concerns discussing about issues relating to people smuggling, human trafficking, and related transnational crime.

\subsection{Politeness Strategy: Off-Record}

All of data shows that Julie Isabel Bishop applies politeness strategy off-record. She applies the strategy by using certain words containing ambiguity. In addition, she applies the indirect answer toward the question from the interviewer. Therefore, Julie Isabel Bishop gives the interviewer (the hearer) interpret what she says.

\section{CONCLUSION AND RECOMMENDATION}

As stated in introduction, this research attempts to investigate types of situations and types of politeness strategy used in diplomatic press release transcription. The finding of this research regarding to the data is the type of situations occur is consultative style because the communication occurs in semi-formal communication and two-way conversation.

In addition, situational context in the communication is taking place when Indonesia and Australia is holding an annual politic dialogue forum named The Bali Process discussing about issues relating to people smuggling, human trafficking, and related transnational crime.

In all of data, politeness strategy found is politeness strategy off-record. According to the data Julie Bishop (the speaker) always does FTA by letting the journalist (the hearer) interpret what she says. Julie Bishop applies ambiguity answers to response the journalist's question.

To sum up, politeness strategy found in diplomatic press release transcription applies off-record because the speaker wants to the hearer interpret what she says; moreover, the speaker implies that she is trying to keep certain information from the hearer.

\section{ACKNOWLEDGMENTS}

This research was supported by a grant from Universitas Padjadjaran in Fundamental Research Scheme.

\section{REFERENCES}

[1] Austin, J. 1962. How to Do Things with Words. Massachusetts: Harvard University Press. 
[2] Cohen, Philip R. dan Hevesque, Lector J. 2010. Performatives in a Rationally Based on Speech Acts Theory.Proceedings of the 28th annual meeting on Association for Computational Linguistics. Page 79-88.

[3] Djajasudarma, Fatimah. 1993. Metode Linguistik: Ancangan Metode Penelitian dan Kajian. Bandung: PT Eresco.

[4] 2012. Wacana dan Pragmatik. Bandung: PT Refika Aditama.

[5] Eckardt, Regine. Hereby explained: an Event based account of Performative Utterances. Linguist and Philos (2012) 35 page 21-55. Published 2 June 2012. (akses, 5 Februari 2014).

[6] Flor, Alicia Martinez and Juan, Esther Uso. Speech Act Performance: Theoretical, Empirical, and Methodological Issues. 2010. John Benjamin Publishing Company

[7] Joos, Martin. 1962. The Five Clocks. Bloomington: Indiana University Research Center.

[8] Mahsun. 2005. Metode Penelitian Bahasa: Tahapan Strategi, Metode, dan Tekniknya. Jakarta: PT Raja Grafinso Persada.

[9] McManis, Carolyn et al. 1987. Language Files. Ohio. Advocate Publishing Group.

[10] Mesthrie Rejend. 2001. Concise Encyclopedia of Sociolinguistics. Elsevier: Oxford UK.

[11] Ofer Fain and Asa Kasher (1996). Journal of Pragmatics 26. hal 793-808. How to Do Things in Words and Gestures in Comics. (accessed October 2012) .

[12] Robinson, Douglas. Introducing Performative Pragmatics. New York: Routledge.

[13] Searle, John R. Speech Acts. 1969. Cambridge: Cambridge University Press

[14] Searle, John R. Indirect Speech Acts . 1975 in Syntax and Semantics Volume 3: Speech Acts. Edited by Cole, Peter and Morgan, Jerry L. New York: Academic Press

[15] Searle, John R. Expression and Meaning. 1999. NY: Cambridge University Press.

[16] Sugiyono. 2013. Metode Penelitian Kuantitatif, Kualitatif, dan R\&D. Bandung: Penerbit Alfabeta

[17] Vavrinchik RJ. Performative Utterances in Recent Newspaper Feature Article.

a. International Scientific Conference "Theoretical and Applied Philology" (22-23 August 2011).

[18] https://prezi.com/myhrvchgq407/types-of-speech-styles/

a. (accessed on July 28, 2017).

\section{AUTHOR's BIOGRAPHY}

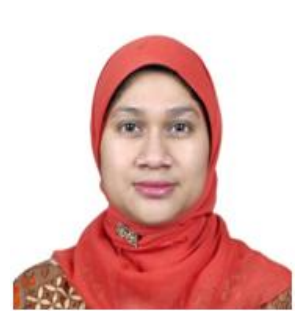

Dr. Rosaria Mita Amalia is a senior lecturer from English Literature, Faculty of Cultural Sciences, Universitas Padjadjaran. She is also recognized as a member of Department of Linguistics. Her research interests lie in the area of Pragmatics, (Critical) Discourse Analysis, Language and Diplomacy and Culture, ranging from theory to design to implementation.Her current research are about Indonesian Diplomacy Strategy through Politeness of Language between Indonesia and Australia which is supported by Universitas Padjadjaran in Riset Fundamental Unpad scheme and Globalization of West Java Cuisine through Soft Power Diplomacy funded by Universitas Padjadjaran through Academic Leadership Grant scheme.She also writes student and teacher English books for deaf students grade 10 with the title Speak up Your Mind in English. The writing of the books are supported by Indonesian Ministry of Education and Culture and can be downloaded at http://bse.kemdikbud.go.id.

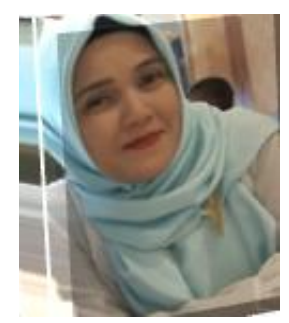

Dr. Elvi Citraresmana is a senior lecturer in Faculty of Cultural Sciences Universitas Padjadjaran. Her interest are in Corpus Linguistics and Semantic Cognitive. Some of her publications are 'Politeness' Gradation In Sundanesse's School Books Elementary In Bandung West Java-Indonesia' presented in Simposium Kebudayaan Indonesia Malaysia; held in Universiti Kebangsaan Malaysia on November 2015, 'The Concept of Love Bandung Mayor Ridwan Kamil Observed from Articles Published in Newspaper and Social Media in Indonesia: A Semantic Cognitive Approach', Malaysian Journal of Communication Jilid 34(2) 2018.

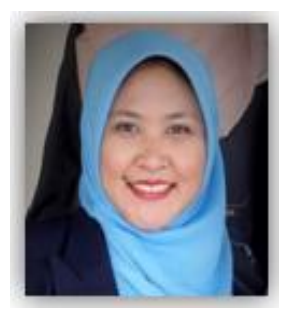

Nurul Hikmayaty Saefullah, M.Humis a lecturer at the Department of French, Faculty of Cultural Sciences, Universitas Padjadjaran, Indonesia. She teaches French Language, Sociolinguistics, Research Methodology, and Translation. Her interests are in subjects of Linguistics, Sociolinguistics, and Translation Studies. She was presenter on "The $16^{\text {th }}$ Biennial Symposium on Literature and Culture in Asia and the Pacific Region: The Forbidden" held in The Philippines (2015) and was presented a paper on translation entitled "Joking Around: Transgressing 
Cultural Constraints in Le Médecin malgré lui and Kabayan Jadi Dukun". She also gave a paper presentation with her colleague on "Artis @ Bangkok 2017: Translatorship" held in Thailand (2017) in the subject of "The Role of Students' Socio-Cultural Background Towards the Quality of Translation: A Case Study in The Translation Class at French Department, Universitas Padjadjaran".

Citation: Rosaria Mita Amalia, Elvi Citraresmana, Nurul Hikmayaty Saefullah. "Diplomatic Strategy Between Indonesia-Australia through Politeness Strategy in Pragmatic Study" International Journal on Studies in English Language and Literature (IJSELL), vol 6, no. 8, 2018, pp. 15-21. doi: http://dx.doi.org/10.20431/2347-3134.0608002.

Copyright: (C) 2018 Authors. This is an open-access article distributed under the terms of the Creative Commons Attribution License, which permits unrestricted use, distribution, and reproduction in any medium, provided the original author and source are credited. 